\title{
Mutations in WDR62 gene in Pakistani families with autosomal recessive primary microcephaly
}

\author{
Rizwana Kousar ${ }^{1}$, Muhammad Jawad Hassan², Bushra Khan ${ }^{1}$, Sulman Basit', Saqib Mahmood ${ }^{3}$, Asif Mir ${ }^{4}$, \\ Wasim Ahmad ${ }^{1}$ and Muhammad Ansar ${ }^{1 *}$
}

\begin{abstract}
Background: Autosomal recessive primary microcephaly is a disorder of neurogenic mitosis that causes reduction in brain size. It is a rare heterogeneous condition with seven causative genes reported to date. Mutations in WD repeat protein 62 are associated with autosomal recessive primary microcephaly with cortical malformations. This study was initiated to screen WDR62 mutations in four consanguineous Pakistani families with autosomal recessive primary microcephaly.

Methods: As part of a large study to detect the genetic basis of primary microcephaly in Pakistan, homozygosity mapping and DNA sequencing was used to explore the genetic basis of autosomal recessive primary microcephaly in four families.
\end{abstract}

Results: Four out of 100 families recruited in the study revealed linkage to the MCPH2 locus on chromosome 19, which harbor WDR62 gene. DNA sequencing in these MCPH2 linked families result in the identification of a novel nonsense mutation (p.Q648X) and three previously known mutations.

Conclusion: Our data indicate that WDR62 mutations cause about 4\% of autosomal recessive primary microcephaly in Pakistan.

\section{Background}

Primary autosomal recessive microcephaly $(\mathrm{MCPH})$ is a congenital disorder, initially characterized by architecturally normal brain but of reduced size associated with mild to moderate mental retardation. However recent studies have broadened the phenotypic spectrum of $\mathrm{MCPH}$ gene mutations by associating additional cortical anomalies [1-4]. Autosomal recessive primary microcephaly is a heterogeneous disorder with seven causative genes reported to date. These include MICROCEPHALIN at MCPH1 [5], CDK5RAP2 at MCPH3 [6]CEP152 at $M C P H 4$ [7], $A S P M$ at $M C P H 5$ [8], CENPJ at MCPH6 [6], STIL at MCPH7 [9] and WDR62 at MCPH2 [1-3].

In Pakistani population, mutations in WDR62 are second most common cause of MCPH. WDR62 (NM_001083961) gene maps to chromosome 19q13.12 and encodes two alternative WDR62 transcripts in humans, however full length transcripts comprise 32

\footnotetext{
* Correspondence: ansar@qau.edu.pk

'Department of Biochemistry, Faculty of Biological Sciences, Quaid-i-Azam

University, Islamabad, Pakistan

Full list of author information is available at the end of the article
}

coding exons encoding a 1,523 amino acid protein. Mutations in WDR62 in five Pakistani families have been reported by Nicholas et al. [2]. In present work, we report identification of a novel and three known mutation in WDR62 gene in four additional Pakistani families with autosomal recessive primary microcephaly.

\section{Methods}

Study subjects

Approval to conduct present study was obtained from the Institutional Review Board of Quaid-i-Azam University (Quaid-I-Azam U IRB\#1- Biomedical; IORG0002926; IRB00003532), Islamabad. Written informed consents were taken from the parents of affected individuals who agreed to participate in the current study by conforming to Helsinki Declaration and local legislations. As part of a large study to address the prevalence and genetic basis of primary microcephaly in Pakistan, 100 families were initially identified and recruited based on the reduced head circumference of affected individuals assessed during field visits in different areas of the Pakistan. Affected probands of
C Biomed Central

() 2011 Kousar et al; licensee BioMed Central Ltd. This is an Open Access article distributed under the terms of the Creative Commons Attribution License (http://creativecommons.org/licenses/by/2.0), which permits unrestricted use, distribution, and reproduction in any medium, provided the original work is properly cited. 
cooperative families were clinically examined at Children Hospital, Lahore to record relevant biometric data followed by radiological examination (X-rays and CT scan).

\section{Extraction of Genomic DNA and Genotyping}

Genomic DNA was extracted from venous blood samples following a standard phenol chloroform procedure. Homozygosity mapping was performed in these families, to test linkage to MCPH1-6 loci as described previously in [10] and to MCPH7 by genotyping D1S2797, D1S3714, D1S2720, D1S3315, D1S2748, D1S1661 and D1S386 markers. Genetic map distances of the markers were obtained from the Rutgers combined linkage-physical map (36.2) of the human genome [11].

\section{WDR62 sequencing}

WDR62 gene was sequenced in one obligate carrier and two affected members from each of the four families linked to the $M C P H 2$ locus by PCR, amplifying all 32 coding exons and splice junction sites by using a set of 27 primer pairs. Purification of the PCR-amplified DNA was performed with commercially available kit (Marligen Biosciences, Ijamsville, Maryland) and sequencing was performed with Big Dye Terminator v3.1 Cycle Sequencing Kit, with an ABI Prism 310 Genetic Analyzer (Applera, Foster City, California). Sequence variants were identified via Bioedit sequence alignment editor version 6.0.7)

\section{Results}

By homozygosity mapping, four families resulted in linkage with the MCPH2 locus harboring the WDR62 gene. Three families (MCP26, MCP35, MCP67) were located in villages near Lahore in the Punjab province of Pakistan, while fourth family (MCP3) originates from Abbottabad in the Khyber Pakhtunkhwa province. The evaluation of the affected individuals of all families (Figure 1) revealed presence of microcephaly and mental retardation. In these patients, microcephaly was noticed at birth and their head circumferences were between -3 and -7 standard deviations. The affected individuals of these families exhibited similar developmental trajectory without any signs of facial dysmorphism, seizures and autism. Interestingly affected male individuals (IV-5, IV6) of family MCP67 have abnormal sleeping habits. The computerized tomography (CT) scan of the affected individual IV-5 of family MCP67 revealed reduced volume of right cerebral hemisphere and prominent extra axial cerebrospinal (CSF) spaces with ill defined gryal and nuclei pattern (Figure 2). However no local area of brain attenuation and intracerebral blood was observed. Due to the non cooperative behavior and effectiveness of available sedative methods on this individual (IV-5) detailed magnetic resonance imaging (MRI) scan could not be performed.

DNA sequencing analysis of the entire coding region of WDR62 gene identified two truncating mutations (of which one novel) and two previously reported missense mutations (Figure 3). The novel mutation in family MCP67 is a single base pair transversion in exon 15 of the gene (c.1942 C>T) resulting in a premature stop codon (p.Q648X). In family MCP26 an already reported homozygous single base pair insertion (c.3936_3937insC) in exon 30 was observed that changed the reading frame, creating a premature stop codon 50 base pair downstream (p.Val1314ArgfsX18) (Figure 3 ). Additionally two missense mutations were identified in exon 10 (c.1313G $>$ A; p.Arg438His) and 11 (c.1531G>A; p.Asp511Asn) in families MCP35 and MCP3, respectively. These mutations were homozygous in affected individuals and found heterozygous in obligate carriers and were not found in 100 control individuals of Pakistani origin.

\section{Discussion}

To date 18 mutations have been reported in WDR62 gene (Table 1) which are associated predominately with primary microcephaly but additional features like pachygyria with cortical thickening and hypoplasia of the corpus callosum, schizencephaly and polymicrogyria were also found in few patients [1-4]. The current study describes identification of two protein truncating and two missense mutations in WDR62 gene in four consanguineous Pakistani families originating from Punjab and Khyber Pakhtunkhwa province.

The p.Val1314ArgfsX18 truncating mutation identified in family MCP26 had already been reported in a Turkish family [3], as well as in affected members of Caucasian family [2] with thickened cerebral cortex and simplified gryal pattern leading to severe microcephaly. The affected individuals of family MCP26 also have severe clinical features, but unfortunately CT and MRI scan were not available to make better comparison. In family MCP67, harboring the truncating mutation p. Q648X, the affected subjects also have severe clinical course and ill-defined gyral pattern on brain imaging, in line with the hypothesis that truncating mutations in WDR62 gene are associated with severe microcephaly and associated brain malformations [2]. Indeed, truncating mutations may lead to nonsense mediated decay which results in complete loss of Wdr62 protein, causing the absence of Wdr62 at the spindle poles of the dividing cells. However the affected individuals of families MCP3 and MCP35, carrying known missense mutations, showed milder symptoms and simplified gyral patterns (Data not shown). 

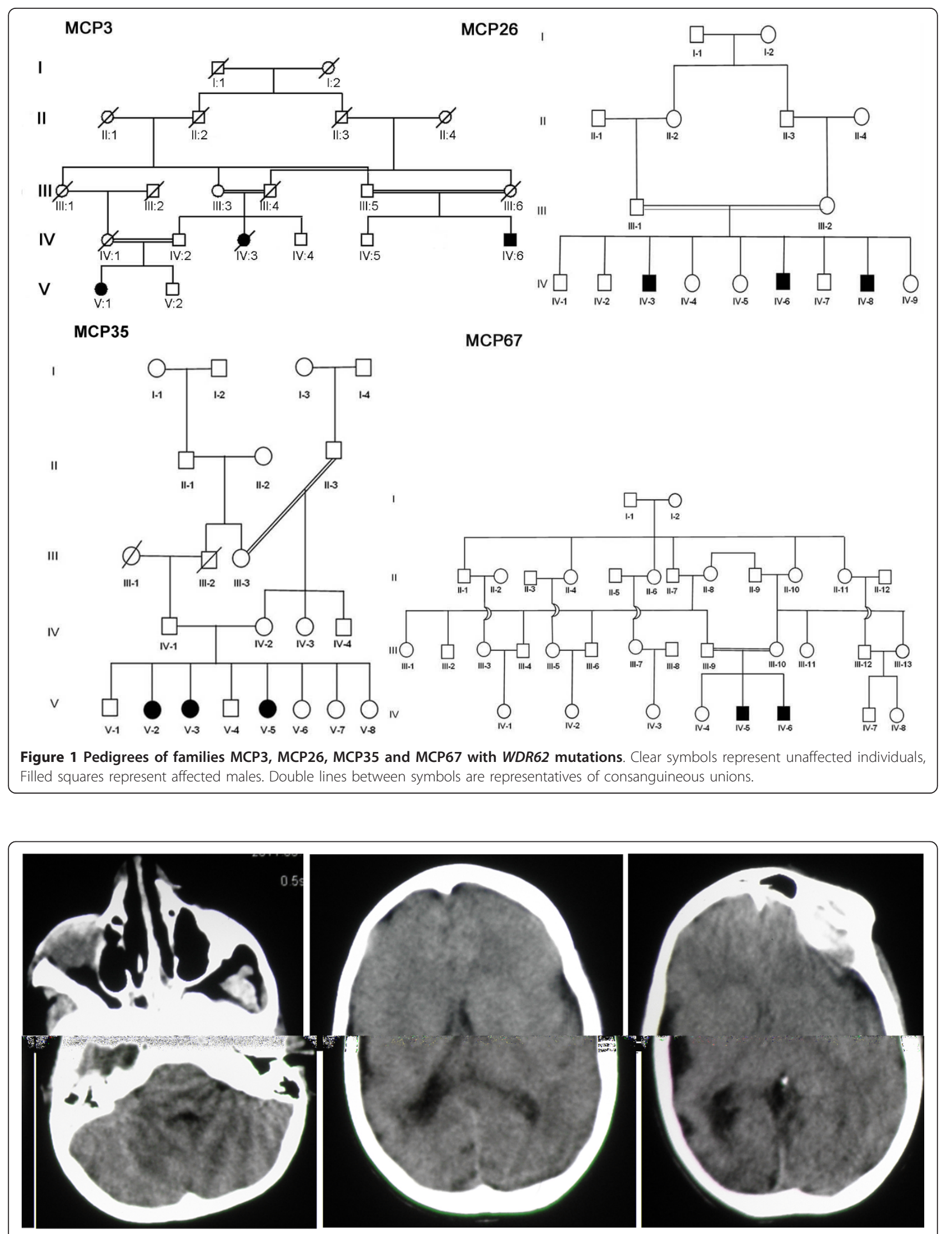

Figure 2 The computerized tomographic (CT) scan of affected individual from family MCP67. The axial CT scan depicts ill defined gryal and nuclei pattern in the affected individual (IV-5) of family MCP67 with homozygous nonsense WDR62 mutation. 


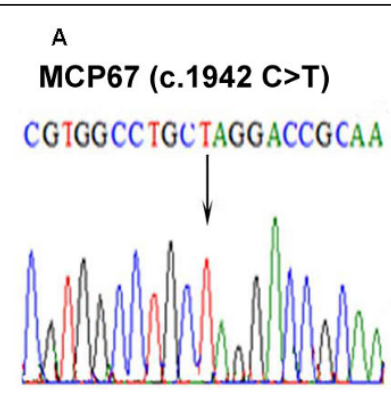

CGTGGCCTGCCAGGACCGCAA

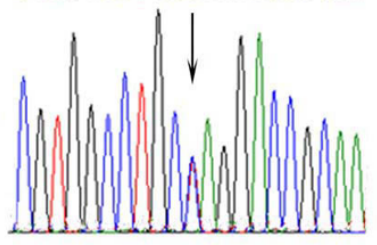

CGTGGCCTGCCAGG ACCGCAA

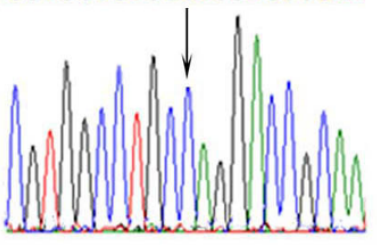

\section{B}

MCP26 (c.3936_3937insC)

GCIGCCCCCCCGIGGATACCCA

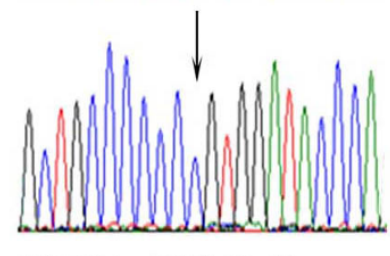

MCP3 (c.1531 G>A)

G GC T TCAG GC A AC C GA A TGG À

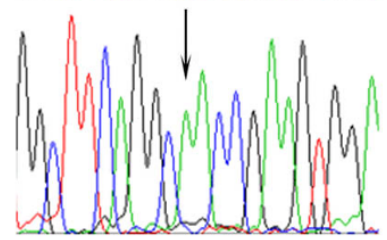

MCP35 (c.1313 G >A)

ACACCATTCACTTCTGGACT

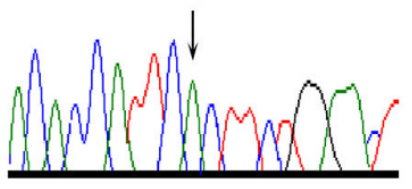

Figure 3 Sequence chromatograms of four probands with WDR62 mutations. A) Sequence chromatogram of family MCP67 with novel WDR62 mutation. The upper panel represents the nucleotide sequence in an affected individual, the middle panel in the heterozygous carrier and the lower panel in the unaffected individual. B) Sequence chromatogram of families MCP3, MCP26 and MCP35 with known WDR62 mutations. Arrows indicate the site of mutation.

Table 1 Pathogenic sequence variants in WDR62 gene reported to date in families mapped to MCPH2

\begin{tabular}{|c|c|c|c|c|c|}
\hline S.No & Nucleotide change & Amino acid change & Location & Ethnic group & Ref paper \\
\hline 1 & $193 \mathrm{G}>\mathrm{A}$ & Val65Met & Exon 2 & Arab & {$[2,3]$} \\
\hline 2 & 363delT & Asp112MetfsX5 & Exon 4 & Mexican & [3] \\
\hline 3 & 535_536insA & Met179fsX21 & Exon 5 & Indian & [4] \\
\hline 4 & $671 \mathrm{G}>\mathrm{C}$ & Trp224Ser & Exon 6 & - & [1] \\
\hline 5 & C. $900 C>A$ & Cys300X & Exon 8 & Indian & [4] \\
\hline 6 & $1043+1 G>A$ & Ser348RfsX63 & Intron 8 & Turkish & [3] \\
\hline 7 & $1313 \mathrm{G}>\mathrm{A}$ & Arg438His & Exon 10 & Pakistani & [2], This study \\
\hline 8 & $1408 C>T$ & Gln470X & Exon 11 & - & [1] \\
\hline 9 & $1531 \mathrm{G}>\mathrm{A}$ & Asp511Asn & Exon 11 & Pakistani & [2], This study \\
\hline 10 & $1576 \mathrm{G}>\mathrm{T}$ & Glu526X & Exon 12 & - & [1] \\
\hline 11 & $1576 \mathrm{G}>\mathrm{A}$ & Glu526Lys & Exon 12 & - & [1] \\
\hline 12 & $1942 \mathrm{C}>\mathrm{T}$ & Gln648X & Exon 15 & Pakistani & This study \\
\hline 13 & 2867+4_c2867+7delGGTG & Ser956CysfsX38 & Intron 23 & Turkish & [3] \\
\hline 14 & $3232 \mathrm{G}>\mathrm{A}$ & Ala1078Thr & Exon 27 & Pakistani & [2] \\
\hline 15 & 3839_3855delGCCAAGAGCCTGCCCTG & Gly1280AlafsX21 & Exon 30 & Turkish & {$[1,3]$} \\
\hline 16 & 3936dupC/3936_3937incC & Val1314ArgfsX18/Nal1314GlyfsX17 & Exon 30 & $\begin{array}{l}\text { Caucasian, } \\
\text { Turkish, } \\
\text { pakistani }\end{array}$ & {$[2,3]$ This study } \\
\hline 17 & 4205delTGCC & Val1402GlyfsX12 & Exon 31 & Eastern Turkey & [1] \\
\hline 18 & 4241dupT & Leu1414LeufsX41 & Exon 31 & Pakistani & [2] \\
\hline
\end{tabular}


Cerebral cortex, the most complex region of mammalian nervous system is formed by the orderly generation of postmitotic neurons during neurogenesis through proliferation and differentiation of neural progenitors at the ventricular and subventricular zones that line the cerebral cavity $[12,13]$. Initially neural progenitor cells divide symmetrically to generate a pool of neural precursors for lateral expansion of neocortex. Subsequently asymmetric neurogenic division perpendicular to their apical-basal axis (horizontal cleavage) renews the precursor cell along with generation of post mitotic neuron [14]. The switch of mammalian neuroepithelium (NE) cells from symmetric, proliferative to asymmetric, neurogenic divisions has been proposed to involve a change in cleavage plane orientation hence depends upon spindle pole positioning [14].

Wdr62 is a spindle pole protein expressed in neuronal precursor cells undergoing mitosis in the mammalian embryonic neuroepithelium [2-4] and hence vital for positioning the cleavage furrow for symmetric proliferative division to increase the number of neuronal precursor cells [2]. Therefore, mutated wdr62 may results in depletion of progenitor pool affecting the proliferation rate and thus produce reduced neuron numbers causing primary microcephaly. Nicholas et al. [2] furthermore hypothesized that WDR62 is also involved in neuronal migration and mutated wdr62 may cause cortical lamination defect along with impairing centrosomal function.

\section{Conclusion}

This study supports the notion that WDR62 mutations results in brain malformations in addition to primary microcephaly irrespective of family origin and ethnicity. Furthermore it also indicates that beside ASPM, WDR62 gene is a relevant contributor for autosomal recessive primary microcephaly in Pakistan, being responsible for about $4 \%$ cases.

\section{Acknowledgements}

We wish to thank all the members of the four families for their voluntary participation and cooperation with this study. RK was supported by Indigenous Scholarship and International Research Support Program (IRSIP) from the Higher Education Commission (HEC) of Pakistan. This research was supported by grant from the HEC (NRPU-1118).

\footnotetext{
Author details

${ }^{1}$ Department of Biochemistry, Faculty of Biological Sciences, Quaid-i-Azam University, Islamabad, Pakistan. ${ }^{2}$ Department of Biochemistry, University of Health Sciences, Khayaban-e-Jamia Punjab, Lahore, 54600, Pakistan. ${ }^{3}$ Department of Human Genetics and Molecular Biology, University of Health Sciences, Khayaban-e-Jamia Punjab, Lahore, 54600, Pakistan. ${ }^{4}$ Department of Bioinformatics and Biotechnology, International Islamic university, $\mathrm{H}-10$, Islamabad, Pakistan.
}

\section{Authors' contributions}

MJH, SB, SM and AM identified, recruited and clinically evaluated the subjects. RK, MJH and BK did the DNA extraction, genotyping and homozygosity mapping. RK, AM and SB performed sequencing of WDR62 gene in four families and control samples. In addition to manuscript writing the study was designed and supervised by WA and MA. All authors have read and approved the final manuscript.

\section{Competing interests}

The authors declare that they have no competing interests.

Received: 14 June 2011 Accepted: 1 October 2011

Published: 1 October 2011

\section{References}

1. Bilgüvar K, Oztürk AK, Louvi A, Kwan KY, Choi M, Tatli B, Yalnizoğlu D, Tüysüz B, Cağlayan AO, Gökben S, Kaymakçalan H, Barak T, Bakircioğlu M, Yasuno K, Ho W, Sanders S, Zhu Y, Yilmaz S, Dinçer A, Johnson MH, Bronen RA, Koçer N, Per H, Mane S, Pamir MN, Yalçinkaya C, Kumandaş S, Topçu M, Ozmen M, Sestan N, Lifton RP, State MW, Günel M: Whole-exome sequencing identifies recessive WDR62 mutations in severe brain malformations. Nature 2010, 467:207-210.

2. Nicholas AK, Khurshid M, Désir J, Carvalho OP, Cox JJ, Thornton G, Kausar R, Ansar M, Ahmad W, Verloes A, Passemard S, Misson JP, Lindsay S, Gergely F, Dobyns WB, Roberts E, Abramowicz M, Woods CG: WDR62 is associated with the spindle pole and is mutated in human microcephaly. Nat Genet 2010, 42:1010-1014

3. Yu TW, Mochida GH, Tischfield DJ, Sgaier SK, Flores-Sarnat L, Sergi CM, Topçu M, McDonald MT, Barry BJ, Felie JM, Sunu C, Dobyns WB, Folkerth RD, Barkovich AJ, Walsh CA: Mutations in WDR62, encoding a centrosome associated protein, cause microcephaly with simplified gyri and abnormal cortical architecture. Nat Genet 2010, 42:1015-1020.

4. Bhat V, Girimaji S, Mohan G, Arvinda H, Singhmar P, Duvvari M, Kumar A: Mutations in WDR62, encoding a centrosomal and nuclear protein, in Indian primary microcephaly families with cortical malformations. Clin Genet .

5. Jackson AP, Eastwood H, Bell SM, Adu J, Toomes C, Carr IM, Roberts E, Hampshire DJ, Crow YJ, Mighell AJ, Karbani G, Jafri H, Rashid Y, Mueller RF, Markham AF, Woods CG: Identification of Microcephalin, a protein implicated in determining the size of the human brain. Am J Hum Genet 2002, 71:136-142.

6. Bond J, Roberts E, Springell K, Lizarraga SB, Scott S, Higgins J, Hampshire DJ, Morrison EE, Leal GF, Silva EO, Costa SM, Baralle D, Raponi M, Karbani G, Rashid Y, Jafri H, Bennett C, Corry P, Walsh CA, Woods CG: A centrosomal mechanism involving CDK5RAP2 and CENPJ controls brain size. Nat Genet 2005, 37:353-355.

7. Guernsey DL, Jiang H, Hussin J, Arnold M, Bouyakdan K, Perry S, BabineauSturk T, Beis J, Dumas N, Evans SC, Ferguson M, Matsuoka M, Macgillivray C, Nightingale M, Patry L, Rideout AL, Thomas A, Orr A, Hoffmann I, Michaud JL, Awadalla P, Meek DC, Ludman M, Samuels ME: Mutations in centrosomal protein CEP152 in primary microcephaly families linked to MCPH4. Am J Hum Genet 2010, 87:40-51.

8. Bond J, Roberts E, Mochida GH, Hampshire DJ, Scott S, Askham JM, Springell K, Mahadevan M, Crow YJ, Markham AF, Walsh CA, Woods CG: ASPM is a major determinant of cerebral cortical size. Nat Genet 2002 32:316-320.

9. Kumar A, Girimaji SC, Duvvari MR, Blanton SH: Mutations in STIL, encoding a pericentriolar and centrosomal protein, cause primary microcephaly. Am J Hum Genet 2009, 84:286-290.

10. Gul A, Hassan MJ, Mahmood S, Chen W, Rahmani S, Naseer MI, Dellefave L, Muhammad N, Rafiq MA, Ansar M, Chishti MS, Ali G, Siddique T, Ahmad W: Genetic studies of autosomal recessive primary microcephaly in Pakistani families. Novel sequence variants in ASPM gene. Neurogenetics 2006, 7:105-110.

11. Matise TC, Chen F, Chen W, De La Vega FM, Hansen M, He C, Hyland FC, Kennedy GC, Kong X, Murray SS, Ziegle JS, Stewart WC, Buyske S: A second-generation combined linkage-physical map of the human genome. Genome Res 2007, 17:1783-1786.

12. Kim S, Lehtinen MK, Sessa A, Zappaterra MW, Cho SH, Gonzalez D, Boggan B, Austin CA, Wijnholds J, Gambello MJ, Malicki J, LaMantia AS, Broccoli V, Walsh CA: The apical complex couples cell fate and cell survival to cerebral cortical development. Neuron 2010, 66:69-84.

13. Wollnik B: A common mechanism for microcephaly. Nat Genet 2010 , 42:923-924. 
14. Chenn A, McConnell SK: Cleavage orientation and the asymmetric inheritance of Notch1 immunoreactivity in mammalian neurogenesis. Cell 1995, 82:631-641.

\section{Pre-publication history}

The pre-publication history for this paper can be accessed here: http://www.biomedcentral.com/1471-2377/11/119/prepub

doi:10.1186/1471-2377-11-119

Cite this article as: Kousar et al.: Mutations in WDR62 gene in Pakistani families with autosomal recessive primary microcephaly. BMC Neurology 2011 11:119.

Submit your next manuscript to BioMed Central and take full advantage of:

- Convenient online submission

- Thorough peer review

- No space constraints or color figure charges

- Immediate publication on acceptance

- Inclusion in PubMed, CAS, Scopus and Google Scholar

- Research which is freely available for redistribution 